Article

\title{
Decolonization of Trauma and Memory Politics: Insights from Eastern Europe
}

\author{
Dovile Budryte
}

Received: 16 November 2015; Accepted: 13 January 2016; Published: 18 January 2016

Academic Editor: Sonya Andermahr

School of Liberal Arts, Georgia Gwinnett College, 1000 University Center Lane, Lawrenceville, GA 30043, USA; dbudryte@ggc.edu

\begin{abstract}
The movement to decolonize trauma theory conceptualizes traumas as rooted in particular contexts. Scholars working within this framework caution against the monumentalism of traumas as singular events and press for the acknowledgment of traumas experienced by minorities and liminal groups. In addition, this body of literature suggests a question of fundamental significance to memory politics: How to make sure that postcolonial attempts to memorialize the traumatic histories of colonialism do not become sources of state subjugation and oppression? Using examples from Eastern Europe, this article analyzes the complexity of memory landscapes in this region and the difficulty of acknowledging traumas of "non-Western" groups on their own terms. Drawing on works by three authors from the region (Ene Kõresaar, Svetlana Aleksievich and Jasmina Husanović), this essay identifies alternative ways of thinking about the nexus of trauma and difference by addressing how complexity and vulnerability can help to transcend competing victimhoods in Eastern Europe and elsewhere.
\end{abstract}

Keywords: traumatic memory; Eastern Europe; the Baltic states; memory politics; postcolonialism

\section{Introduction}

Stef Craps argued persuasively for a reshaping of what he described as Western, event-based models to address traumas. In Postcolonial Witnessing, Craps went as far as to suggest that "the traumas of non-Western or minority groups must also be acknowledged on their own terms" ([1], p. 3). In the eyes of Craps and other authors advocating for the decolonization of trauma theory, such an approach requires the inclusion of the lived experiences of subordinate groups by paying attention to real human bodies, power politics and humiliations that can last a long time (for example, under colonization). Similarly, the contributors to this special journal issue engage with various experiences from the global South (e.g., the Philippines and Cambodia; [2,3]) and its neighborhood (e.g., the Australian aborigines [4]) to address the issues raised by Craps and to outline an alternative to what is considered to be Western trauma theory. These cases fit into postcolonial modes of analysis, with the identifiable hegemons and subalterns.

This essay aspires to contribute to the attempts to decolonize trauma theory in two ways. First, I propose that attempts to decolonize trauma theory should acknowledge multiple challenges associated with the proposed recognition of the traumas experienced by "non-Western" or minority groups on their own terms. These challenges include ethical and practical issues related to the existing global power structures, cultural norms, historical legacies and raise complicated questions, such as: "Who has the power to engage in politics of recognition?" and "What should be done with potentially problematic 'non-Western' narratives that can introduce new lines of division and competing victimhoods?" It is important to remember that there is a crucial distinction between surviving a trauma and receiving its memory or representation of memory. As Debarati Sanyal pointed 
out, "the overwhelming focus on victimhood in the reception of such [traumatic] memory can lead to appropriation of stories that are not our own and can even become alibis for the perpetration of violence" ([5], p. 8). I illustrate my point about challenges presented by potentially problematic "non-Western" narratives by discussing several cases of memory politics and memory entrepreneurship from Eastern Europe, mostly from the Baltic states-the region with which I feel most familiar.

Second, as implied by those who argue for decolonization of trauma theory I suggest that carefully listening to traumatic stories told by various groups, may allow us to search for connections between individuals and groups with different traumatic experiences. Highlighting the complexity of traumatic situations such as political violence, war or genocide, as well as understanding the common vulnerabilities of humanity can help us to transcend competing victimhoods and resist political exploitation of trauma. I support my proposal with insights from several authors who wrote about traumatic experiences and explored trauma narratives in Eastern Europe.

Why is Eastern Europe a suitable region for discussion? Also known as the "Other Europe", the former Soviet sphere of influence, or postcommunist Europe, this region experienced some of the worst political violence in human history during the previous century, including the Holocaust, the two World Wars, widespread repression of human rights, mass deportations, and ethnic cleansing. Parts of the region are still reeling from "low intensity" political violence today. As a result of these developments, there are still areas of this region where various groups compete for recognition of "their" trauma, "their" past and refuse to acknowledge the right of other groups' pasts to co-exist in the same memory space. As argued astutely by Alexander Etkind, in contrast to the Nazi terror, where the line between victims and perpetrators was clear, the Soviet terror during the Stalinist time targeted various ethnic and social groups. Often the lines between the victim and perpetrator were not clear, and the same person could be a perpetrator during one wave of terror, and the victim during the next ([6], p. 8).

This historical context provides many opportunities to test the main tenets of trauma theory (including the "eventness" and "monumentalism" of traumas) and think about the ways to decolonize it, in order to do justice to these various complex experiences. Perhaps most importantly, the cases from Eastern Europe may challenge us to think about the assumptions embedded in the use of the term "the West", especially now, when a large part of this region, including the former Soviet republics of Lithuania, Latvia and Estonia, have been part of the Western international institutions, including the European Union, for a while, and were able to affect the European mnemonic landscape by introducing different trauma narratives.

These observations and questions, however, do not negate the value of the main tenets of the movement to decolonize trauma theory-specifically, its call to pay attention to real bodies, power politics and everyday traumatic experiences. In particular, I believe that a call to focus on real bodies and everyday traumatic experiences instead of "monumental traumas" has the power to transcend the both real and imagined divisions between the "West" and "non-West" and similar entities.

Paradoxically, the proposed foci on real bodies brings us back to some of the original insights of trauma theory as articulated by Cathy Caruth [7] and others-that experiences of traumas do not need to be divisive; they can become sources of compassion and radical relationality, transcending ethnic and cultural divisions. To make this point, the essay engages the works of Nobel Prize winner Svetlana Aleksievich [8] and political philosopher Jasmina Husanović $[9,10]$. I believe that the approaches to the study of trauma developed by these thinkers embody a search for the ways to belong to both the "West" and "non-West" at the same time. In addition, it seems that these authors have successfully challenged problematic and exclusionary national myths and ethno-nationalist identities based on traumas that probably should not be acknowledged "on their own terms". To give examples of problematic trauma stories and explain how they are related to postcolonial identities, I draw on a case of memory entrepreneurship studied by ethnologist Ene Kõresaar [11,12].

In their works, these authors have presented different ways to think about war, a major traumatic experience. In Western discourses and imaginations, war is often depicted as a monumentally traumatic 
event, usually with a clear beginning (for example, 1 September 1939 for World War II) and a clear end (8 May 1945 for World War II). However, in parts of Eastern Europe, for example, the Baltic states, World War II and its aftermath are remembered very differently, as a long lasting trauma related to colonization with no clear beginning and no clear end. The approaches the three authors addressed in this essay help us to think about war as a traumatic experience in a "non-eventful" way, paying attention to "mundane" everyday details (Aleksievich), focusing on its aftermath (Husanović) and linking it to colonization (Kõresaar).

Aleksievich wrote about the experiences of Soviet women veterans and the ways that they remember World War II (known as the "Great Patriotic War" in Russia and Belarus); Husanović explored the possibilities of safe spaces for mourning for women who have suffered from war in the Balkans, and Kõresaar analyzed the ways in which World War II is remembered by men in Estonia, some of whom fought for the Soviet Union, and others-for Nazi Germany. In addition, these three authors outlined different ways to think about individual traumatic experiences and political structures simultaneously, thus proposing new ways to decolonize trauma theory. Hopefully, looking for the intersections between individual traumatic experiences and political power structures in their works will help me to distill specific strategies to acknowledge traumas experienced by individuals belonging to different groups but at the same time remain cognizant of common humanity. By engaging with their work, I hope to move closer to the goal articulated by Craps in Postcolonial Witnessing: namely that trauma theory "need not be abandoned altogether but can and should be reshaped, resituated, and redirected so as to foster attunement to previously unheard suffering" ([1], p. 37).

Consequently, this essay is structured in the following way: First, by paying attention to various hierarchies and power constellations, I will identify the leading traumatic memory discourses and outline the contours of memory cultures in Eastern Europe. Second, I will briefly discuss a complicated relationship between the "Other" Europe and political discourses about (post)colonialism, analyzing how discourses about colonialism could and have been used in ethnic entrepreneurship and memory politics. While acknowledging fascinating insights about Eastern Europe from various perspectives that can be described as "postcolonial studies" (e.g., [13-17], etc.), I am particularly interested in exploring how political discourses about colonialism can help to claim ownership of historical traumas, and how this ownership can turn into potentially problematic narratives. Finally, drawing on the works of the three authors mentioned above, I will discuss what I believe are promising ways to think about the intersections between traumatic memories related to war and power structures in Eastern Europe and elsewhere, thus contributing to the movement to decolonize trauma theory.

\section{Dominant Memory Discourses and Memory Cultures in the "Other" Europe}

To make sense of memory cultures in Eastern Europe in 2004 (the year when the European Union, accepted ten new members from the region), Stefan Troebst developed four categories of societies. The first category was used to describe societies, such as the Baltic states, in which there has been a strong anticommunist feeling regarding recent history ([18], p. 58). This feeling could be detected by looking at legislation condemning the previous communist regime and the international actions of those state leaders who pushed for the inclusion of the remembrance of the Stalinist regime into the European mnemonic landscape. The second category was used to describe societies such as Ukraine or Poland with fierce memory battles over the recent past, with camps that included "anticommunist liberals" and "postcommunist socialists" ([18], p. 58). The third category was used to describe states such as Bulgaria or Albania where there was little willingness to address the recent past. Troebst put Belarus and Russia into the fourth category of societies that viewed communism in a mostly positive light, arguing that most people had positive memories about their experiences during that time ([18], p. 58).

Like many attempts to make generalizations about the region, Troebst's scheme does not capture those memory battles that took place within societies associated with each category. For example, Eva-Clarita Pettai's collection of case studies focusing on memory politics in the Baltic states has convincingly documented the pluralism of memories within these three states [19]. Without denying 
the existence of this pluralism of memories and counter-memories, it is still possible to identify several leading discourses about traumatic memories in Eastern Europe.

One of those discourses relates to nation-building myths rooted in traumas, often with the use of the term "genocide". As argued by Evgeny Finkel [20], after the disintegration of the Soviet Union, the use of the term "genocide" to describe the crimes of Communist regimes has been embraced not only by Lithuania (which is probably one of the internationally most well-known cases; see [21]), but also by other post-Soviet states. Similarly, many authors explored the ways in which memory of Holodomor (death by hunger) has become one of the founding myths of the post-Soviet Ukrainian state (e.g., [22-24] and others). This discourse has been subject to intense criticism by those who believe that it is used to engage in "comfortable victimhood", and even to obscure other major traumas, including the Holocaust (e.g., $[24,25])$.

Given the enormity of the Stalinist repressions (including deportations, widespread imprisonment and death by hunger), it is understandable that such enormous traumas are remembered and commemorated-not only in the geographical areas where they occurred, but also beyond. Instead of attempting to find commonalities with the traumas experienced by other groups, memory entrepreneurs (especially in multiethnic areas) often attempt to claim exclusive ownership of these traumas, an approach that can become a reason for concern and an example of how such traumas can become transformed into problematic narratives. Memory entrepreneurs tend to mobilize their energies to promote the version of the past that they strongly believe in, and they get engaged in various political and social activities to gain support for their cause. However, attempts to minimize the extent of these repressions and trivialize their memories can be equally, if not more, problematic.

There are some signs that traumatic memory regimes based on exclusive national traumas are being challenged. During the past decade, in many East European societies Holocaust commemorations became much more common and visible. Both international and local actors have been engaged in various memory projects such as exhibitions, ceremonies, films, plays, and marking of the sites of mass killings, to mention just a few. There are many attempts to localize the Holocaust memories by organizing impactful commemorations in the places where mass killings took place. An example of such impactful monuments is a road of candles in the forest where mass killings of Lithuania's Jews took place. In the words of one of my students at Vilnius University (where I taught a course on trauma and memory in Fall 2015), who made a distinction between "usual" and "unusual" monuments: "The one in Varnikai (a small town in Eastern Lithuania), near lake Skaistis, where about 1500 Jews were killed [is an unusual monument]. It's a long pathway through the forest which you enter through a wicket ... an eerie flat pathway surrounded by trees, that's unusual but powerful ... candles put in the ground."

Arguably, this is a drastic change in remembrance practices, and it is happening not only in the states that such as Lithuania (which is a member of the European Union, and the Holocaust remembrance was encouraged by this international organization), but also in Ukraine, which is not a member of the European Union. This observation implies that the Holocaust memory is becoming a transnational memory in Eastern Europe. In the words of Volodymir Kulyk, "To be frank, because of the organizations of Ukrainian Jews, interested in memory work, activism demonstrated by the states of Israel and Western states who influenced the government of Ukraine and intellectuals, this narrative [of the Holocaust] has transcended ethnic boundaries and became part of Ukraine's popular history. This also has happened in the West, and during the recent years-also in post-Communist states" [26].

Kulyk's assessment of the degree to which the Holocaust became part of popular histories in Eastern Europe is probably a bit too optimistic. There are studies showing that a lot of work that still needs to be done in this area, especially pertaining to education regarding the Holocaust (e.g., see chapters on Poland, Lithuania, Latvia and Estonia in a recently published book on the Holocaust education in various countries [27]). There are anthropological and cultural studies suggesting that the Holocaust is still seen by many ethnic Lithuanians as a tragedy that has affected the "others" (e.g., see [28], p. 4). In addition, at least in the case of the Baltic states, many have trouble 
identifying with the narrative about World War II in which the victorious powers (including the Soviet Union) are portrayed as heroes, and the losers together with their allies-as villains. As explained by Sužiedelis and Liekis, the leading Holocaust scholars in Lithuania, even the usual dates for World War II (1939-1945) have little resonance in Lithuania, as most ethnic Lithuanians were killed in the war's aftermath (1945-1953), during the irregular war known as pokaris ("post-war"). The "Grand Alliance narrative" in which the USSR is presented in a positive light, is not popular in the Baltic states, and this has led to political difficulties, including Lithuanian-Jewish and Lithuanian-Russian relations ([29], p. 325).

In the Baltic states, many still view the USSR's role in World War II and especially its aftermath (with mass deportations and executions) as disastrous for the fate of the Baltic ethnic Lithuanian, Latvian and Estonian communities. As noted earlier, narratives about World War II are often linked to the broader theme of colonization by the Soviet Union. At the same time, a narrative about the Great Patriotic war and heroism of the USSR is still very popular in Russia, and it is embraced by many Russians, especially those living in Latvia and Estonia. Such situations (when different groups embrace seemingly opposing narratives) makes it challenging for members of those groups to acknowledge their traumas publicly on their own terms. In the Baltic states, state-supported narratives presented in the museums, textbooks and similar spaces do not (and probably cannot) support the "Grand Alliance" or the Great Patriotic war narrative, telling a story about loss of sovereignty instead.

In addition, as pointed out by Alexander Etkind in his analysis of memory in post-Soviet Russia, there are other difficulties with commemorations in Eastern Europe, particularly in those areas which have been subject to severe Stalinism for a long time (such as Belarus and Ukraine) ([6], p. 24). In those areas, various groups cultivate their own militant memories about the past, and thus engage in politicized memory wars. Memories about the Stalinist terror and World War II can become especially salient when memory entrepreneurs who embrace opposing "truths" start fighting for broader recognition of "their" particular traumas and "their" particular histories. Polarizing discourses, including the language about colonialism and oppressive colonial practices, can be used as a weapon in such memory wars and even nation-building projects. Aggressive actions by the former colonial power and its inability to engage in "responsibility in complicity" by acknowledging the crimes of the past related to the colonial legacies (Debarati Sanyal's term, [5], p. 14) can only empower such discourses.

\section{The "Other" Europe and Discourses about (Post) Colonialism}

In the field of postcolonial studies, colonialism is usually associated with shameful actions of the Western powers (also known as the global North), such as extraction of resources, exploitation of populations that are seen as "lesser" than the colonizers, subjugation of the system of education to the norms of the colonizers, etc., in the places now known as the global South. Postcolonial scholars tend to embrace theories and perspectives stemming from Marxism and its focus on "the haves" and "the have-nots". However, many scholars and practitioners in Eastern Europe find the focus of postcolonial perspectives on the issues of inequality distasteful, preferring to support liberal theories extolling capitalism and individual liberties instead. In addition, many such scholars and practitioners see themselves as belonging to Europe and, in the words of Violeta Kelertas, "find being lumped together with the rest of colonized humanity unflattering" ([30], p. 4).

Although Kelertas' insight about the unwillingness to be considered part of the "underdeveloped world" was meant to capture the relationship between the Balts (Latvians, Lithuanians and Estonians) and their pasts, evidence from other parts of Eastern Europe suggest that the attitudes toward the label of postcolonialism may be similar there as well (see, for example, a description of the ways in which the Polish elites have misused this term presented by Claudia Snochowska-Gonzalez [31]). Belonging to Europe and, by extension to the West, has been considered to be a much more desirable circumstance than belonging to the "Third World", or the "developing world". Furthermore, belonging to Europe (and thus to the West) implies a certain level of superiority vis-à-vis Russia, which is seen as a former non-Western, non-European colonizing power from the East. As David Chioni Moore pointed out, 
postcolonial identities of Central and Eastern Europeans are intertwined with a desire to "return to Western-ness that once was theirs" and thus escape from Russia's "colonial grasp". His observation applies to the Baltic states as well [32].

Academics and politicians in Eastern Europe have used and still use discourses about colonialism to address the Soviet past. For example, after an examination of the main historical developments in the Baltic states during the 20th century, Epp Annus concluded that "colonization" may be an appropriate term to describe the Soviet rule starting with the 1950s (until 1991 when the Baltic states regained their independence from the Soviet Union). During this time, after a long period of resistance, the local populations started to cooperate with the Soviet authorities. She suggested using the term "occupation" to describe the turbulent years of 1941 and 1944-1953 when the Baltic states were occupied by the Soviet Union and experienced mass deportations and other forms of repression ([33], p. 36). There were many criteria to select people to be deported, and "the enemy of the Soviet state" was one of them. Many innocent people were subject to this form of repression. Annus described the Soviet colonialism of this period as including "a diverse spectrum of models of repression and subordination, dependent on the prehistories of separate regions" ([33], p. 26).

In contrast, the term "colonialism" is used differently in politics. For example, in Estonia and Latvia, the terms "colonialism" and "colonists" were widely used in political discourse during the late 1980s and early 1990s when decisions about who would be part of an independent nation and who will not had yet to be made. Traumatic memories about the Stalinist deportations by the Soviet Union that affected many Estonians and Latvians became part of public debates. These Stalinist deportations from Estonia and Latvia to Siberia and immigration of Russian-speakers from other parts of the Soviet Union to Estonia and Latvia were described as unlawful practices by an occupying power, the colonizer. "Decolonization" implied that the creation of an ethnic democracy where the restoration of citizenship only to those who lived in Latvia and Estonia prior to the occupation by the Soviet Union and their descendants (mostly ethnic Balts) was portrayed as legitimate ([34], p. 70). Due to the pressure from the European Union and other international organizations, the two Baltic states made their citizenship laws more inclusive and consistent with the relevant international norms; however, the use of discourse about traumas associated with colonialism was a powerful tool in the hands of ethnic entrepreneurs in the beginning stages of democratization, deepening the lines of ethnic divisions.

This comparison of the ways in which the term "colonialism" was used in different contexts and different settings suggests that this phrase can be integrated into trauma vocabulary and thus incorporated into politics. In such cases, there is a movement away from real lived experiences, real bodies, and real people. Then there is a danger that problematic collective trauma narratives can be constructed-especially if politicians using trauma vocabularies act as "mnemonic warriors", not "mnemonic pluralists", believing that they are the only ones who possess the historical truth and know what aspects of this truth need to be retained in collective memory ([35], p. 13). Consequently, it becomes important to study "memory entrepreneurs" who, in the words of Elizabeth Jelin, "seek social recognition and political legitimacy of one (their own) interpretation or narrative of the past. We will also find them engaged and concerned with maintaining and promoting active and visible social and political attention on their enterprise" ([36], pp. 33-34). Ene Kõresaar's work analyzes the life and work of one such memory entrepreneur.

\section{Deconstructing the Dominant Discourses, Engaging Trauma Theory: Three Perspectives}

In a collection of narratives Soldiers of Memory: World War II and Its Aftermath in Estonian Post-Soviet Life Stories, Ene Kõresaar wrote about the life and narrative of Estonian Boris Takk, who in 1943 was mobilized by the Germans to join the Waffen SS (a German military unit) when he was still a teenager. In 1944 he decided to stay in Estonia (instead of retreating with the German military). This meant a life under the Soviet rule until 1991. In the early 1970s Takk joined the Communist Party of Estonia. In his narrative recorded by Kõresaar, he argued that "he wanted to serve the Estonian cause from inside the system" ([12], p. 347, italics original). Similar phrases were used by many former Communist 
party members in the Baltic states after the disintegration of the Soviet Union who wanted to show their commitment to the cause of nationalism and convince others that they were not true believers in communism.

After Takk joined the Communist Party, his story gets even more interesting. In the late 1980s and early 1990s, when Estonia regained its independence from the Soviet Union, he started to organize gatherings of Estonian veterans of the German military, arguing that theirs and his decision to join the Waffen SS was a "continuous fight for Estonia's freedom", against the Communists ([12], p. 348), italics original). Takk became active politically as a memory entrepreneur, interested in disseminating and fighting for his version of historical "truth". To a degree, he succeeded as his story was heard in Estonia, and he was able to attract followers amongst some Estonians.

The core of Takk's story was a metaphor of "a prolonged rupture" (referring to the long period of the Soviet rule from 1940-1941 and then again from 1944 until 1991), referring to the break in the Estonian national sovereignty caused by the Soviet occupation. In the words of Ene Korresaar, "the life story of Boris Takk ... represents the dominant view of history that evaluates the entire history of Estonia in the 20th century from a postcolonial perspective" ([12], p. 344). According to this perspective, a story about World War II is framed as colonization by Nazi Germany, and the life before and after World War II is also described as survival under another colonizer, the Soviet Union. Perhaps such perceptions of history make "responsibility in complicity" [5], which implies reflexivity and awareness of the past crimes as well as the acceptance of collective guilt, next to impossible. The crimes committed by the locals who collaborated with the occupying powers could be attributed to someone else, that is, the colonizing powers, not the individuals who have committed those crimes.

Like all entrepreneurs of memory, Takk had a strong explicit ideological message, arguing that the Estonians could not lead a "normal" life under the Soviet rule without their own nation-state. Takk's World War II story was not about glory and victories. It was also about excessive drinking, abusing the civilian population, uneasy encounters with pro-Soviet partisans, and sometimes strained relationship with the Germans whom many Estonians (even the ones serving in Waffen SS) saw as colonizers. Interestingly, Takk's story was the only one in this collection of eight narratives (edited by Ene Kõresaar) that mentioned the Holocaust. According to Kõresaar, Takk spoke openly about the Holocaust even before this sensitive topic was openly discussed in public sphere. Takk mentioned the "disappearance" of the Jews and described a concentration camp in Klooga as a "dismal site" ([37], p. 193). There was virtually no discussion of the killing of the Jews during the Holocaust during the Soviet times. The term "katastrofa" was used to refer an immense suffering of the "Soviet people", without referring to separate ethnic groups. The Baltic émigrès in the West avoided this topic as well. Therefore, Takk's willingness to write and talk about the Holocaust in 1993 (a relatively early stage in democratization) can be described as rather unusual.

Takk's story is definitely different from the Western discourses about World War II; therefore, it can be described as "non-Western" or "postcolonial", due to its description of World War II and the Soviet times as colonization. However, what would it mean to acknowledge it on its "own terms"? This story, especially the metaphor of "prolonged rupture" became quite popular in post-Soviet Estonia in the 1990s. However, Takk's memory politics did not achieve a full international or even national recognition. In the nineties, when Estonia was trying to get into the European Union (which was often compared with the re-entry into the West), it became clear that anything related to the glorification of Waffen SS (including a monument depicting an Estonian soldier equipped with an automatic rifle and wearing a German uniform) would not be tolerated by the European Union and many Western-minded Estonian politicians. However, how should the students of memory politics interested in a decolonization of trauma theory handle such "politically incorrect" stories that attract popular imagination but simply do not sound "right"? Simply pretend that they do not exist? Silence them? Condemn them?

First, it may be useful to acknowledge the complexity of the situation. According to Kõresaar, not only the politics of remembrance, but an "autobiographical memory work of those who fought in 
World War II also takes place on this field of tensions" ([11], p. 10). These tensions stem from various international, national and domestic sources, including geopolitical factors, international norms and memory wars. Second, it is necessary to keep in mind that story-tellers have their own interests and agendas. When performing an interview with Boris Takk, Kõresaar recorded (in an endnote) her own feelings, suggesting that Takk may have been "using me as a 'microphone' and addressing the 'Western countries' directly" ([12], p. 358). Third, it is important to recognize other stories about similar traumatic experiences, including counter-memories. As noted earlier, Takk's story was only one out of eight stories about the war experiences of Estonian men, and two out of eight stories are by men who joined the Red Army. Kõresaar decided to include both the original stories and scholarly interpretations of those stories, written by academics (separately from the autobiographical narratives), arguing that "through this prism and approach, we have tried to provide a view into the complexity of commemorating World War II at the end of the 20th century and the initial decades of the 21st century" ([11], p. 2). Biographies were selected to reflect various trajectories of the lives lived by the Estonian men, many of whom ended up fighting their own countrymen as they were mobilized by militaries and governments that fought each other. For example, the photograph from an Estonian family archive on the book cover shows two men standing next to each other and staring into camera, with one wearing a Soviet military uniform, and the other, whose shoulder is touching his companion, wearing a German uniform.

Thinking about similar unruly stories can help those interested in decolonizing trauma theory to ask important questions, such as: "Which lives, and which stories are included into the dominant discourses?" and "Which stories get silenced and why?" As Tiina A. Kirss, one of the contributors to Kõresaar's volume, has observed, the Estonian case of commemorating World War II helps us to think about the hierarchies that are embedded in memory regimes [38]. In the case of the Estonian memory regime that developed after 1991, the highest "honors" were awarded to men who fought with weapons against the Soviet military during World War II and immediately after it. Those who were deported to Siberia were respected as well; so did those who deserted the Soviet military and fled to the West. In contrast, Kirss argues that those men who remained with the Red Army were "in the lowest position" ([38], p. 379). Finally, it appears that women who participated both in this World War II and its aftermath may have been invisible in this particular memory regime.

In her famous book War's Unwomanly Face, Svetlana Aleksievich put forward a compelling narrative, which serves as an alternative to masculine memory regimes. Acknowledging the ongoing appeal of the Great Patriotic war narrative in Russia and Belarus ("we were the children of the victory" ([8], p. 7); "yes, they had Gulag, but also they had Victory" ([8], p. 16), she set out to write a story "not about war, but about a human being in war". Unapologetically, she made her political agenda clear: "Human beings should be larger, greater than war" ([8], p. 7). Aleksievich decided to depict war as experienced by women, which should have "its own colors, its own smells, its own space and its own words" ([8], p. 8). In presenting this perspective, Aleksievich did not hide her frustration that many women, even the ones who fought in the war, were eager to talk about someone else's war and argued that it was time for women to write their own history about war, choosing their own words and using their own feelings.

Similar to Aleksievich's approach to war was feminist scholar Christine Sylvester whose approach, named "touching war", holds that an effective study of war must include the study of the ways in which individuals "touch war and are touched by it in physical, emotional and intellectual ways" ([39], p. 3). Sylvester, Aleksievich and other feminist writers who are not afraid to "touch war", by transcending the narrow focus on military strategy, weaponry, and battlefield tactics that is still embraced by many scholars studying war and related memories. "Touching war" focuses on concrete bodily experiences and therefore makes gender central to the study of war.

Aleksievich was not interested in writing a history of war. Instead, her goal was to write "a history of feelings"; a history of "a small (ordinary) human being" who became subject to the forces of history ([8], p. 13). Yet through listening to the stories and trying to capture "mundane" details about 
everyday war experiences, Aleksievich wants to also capture "the eternal human being" ([8], p. 13); the essence of humanity. She gives memorable examples of how simple human acts of kindness were able to transcend even the front lines, such as how a woman who fought for the Soviet Union extended a piece of warm bread to a suffering German prisoner, and how Soviet nurses decided not to tear off bloody bandages from the German soldiers who served in the hated SS forces ("Protection Squadron").

Her book is full of moving stories about the experiences of women who were active combatants. Aleksievich gives them voice, lets them act; her story tellers are not "merely witnesses; least of all they are witnesses; they are actors and creators" ([8], p. 13). In this way, she helps to "decolonize" traumas by empowering those women who are sharing stories with her. Even their unwillingness to talk, to remember becomes a story narrated by Aleksievich. For example, Aleksievich writes about a woman who wanted to choose silence, asserting her right to silence: "I do not want to remember. Those three years of war ... During these three years, I was not a woman. My body was dead. I did not have menstruations; I did not have female desires. And I was beautiful ... " ([8], p. 11).

One of the findings of Christine Sylvester and others who embraced the same methodology was that there is not one "female" war experience based on victimhood and/or peacemaking. Yet the portrayal of women as "naturally linked to peace" is essential for gender stereotypes and war mythology. As argued by Megan Mackenzie, to challenge these stereotypes it is essential to bring in the individual experiences of female warriors to gain a better understanding of a war's rules ("what is seen to be predictable and standard behavior" during a war) and to "complicate war myths, particularly the warrior/victim myth" ([40], p. 65). Similar conclusions can be made after reading Alexievich's stories about women in war. She writes about women who could not wait to get to the frontlines and fight; women who grew up during war; women who lost their sensitivity to watching and even committing murder, having seen the ashes of their burnt countrymen. She wrote how she was reprimanded by Soviet censors for focusing on "little things" instead of victory in war. However, those "little things" are essential for her story. Alexievich gets in trouble with a Soviet censor who asks her: "Why this biology? You are diminishing women by using this primitive naturalism. Women, who were heroes.... They become ordinary women. We (the Soviet regime) treat them as saints" ([8], p. 17).

This scene raises important questions about the relationship between feminist writers and the state. One of the main functions of a state is to protect its citizens from various threats, real and imagined. If needed, war is waged. The sad truth, pointed out by feminist writers about war, is that women and children as well as other vulnerable groups are most likely to suffer during wars. How can they find safe spaces to tell stories about war that are similar to the one written by Aleksievich, in which war emerges as a horrid experience?

In the eyes of Jasmina Husanović, a feminist philosopher and activist from Tuzla in Bosnia, such spaces exist separately from the state institutions. Husanović argues that it is necessary to pay close attention to power structures that commodify trauma and find ways to transcend them. She starts out by articulating a set of questions inspired by feminist thinking: "What is her voice, where is her space, how is her politics?" and maps out a series of "feminist theoretical and political interventions" that include art ([9], pp. 100-1).

Dwelling on the ways to deal with traumas in societies that have experienced political violence (such as Bosnia), Husanović articulates a stinging critique of liberal attempts to handle traumatic memory with "white gloves" and nationalist attempts to own memory [10]. When writing about liberals trying to handle memory with "white gloves", she is referring to the attempts by the international community to apply instruments of "transitional justice". Such instruments can include trials of perpetrators, truth commissions, and reparations for the victims. Unfortunately, often, as described by Etkind, the lines between the perpetrators and victims are unclear, and transitional justice becomes an illusion [6]. Likewise, the attempts of politicians to claim their exclusive rights to certain pasts (and to use these pasts to pursue their own political goals) can be equally detrimental.

Husanović outlines a third way to deal with traumatic memories. She believes that it is important to search for openings in civil society, which include spaces free from state intervention where art can 
help societies to deal with trauma. Similarly to Alexievich, Husanović pleads for attention to be paid to real women's bodies, so as to create spaces for radical relationality. This is a type of feminist politics, a "politics of witnessing and hope" ([9], p. 103). The goal of this type of politics is to restore dignity to the bodies that have been "defaced, erased and/or violently made non-relevant in the operative biopolitical regimes" ([9], p. 103). By making these bodies visible, and by providing resources to those at the very bottom who struggle for justice and survival, such politics can be transformative.

In her works, Husanović emerges as a scholarly activist, as a writer who embraces action research, working together with civil society activists in searching for ways to undermine the power structures that commodify trauma and impose polarizing stories about traumatic experiences. Husanović's story suggests another dimension that scholars interested in the study of trauma could reflect on; her argument is that someone who writes about trauma needs to be an activist as well, to not be afraid to commit to social and political change. If taken seriously, this argument has serious methodological and philosophical implications.

\section{Conclusions}

In this essay, I attempted to challenge the proposition by Craps to accept "non-Western" traumas on their own terms and warn against an unquestioning acceptance of postcolonial trauma narratives, even if they are produced by the groups who describe themselves or have to live with a prescribed identity of being "non-Western". I also argued that it may be useful to go beyond the "West" and "non-West" dichotomy, looking for the ways to transcend ethnic and national boundaries by working with trauma narratives. The proposition to focus on real bodies and lived human experiences articulated by the movement to decolonize trauma theory suggests one way to resist the attempts to own trauma and memory by various groups.

Engaging works by three authors from the "Other" Europe helped me to support my argument with examples. Boris Takk's story, as told by Ene Kõresaar, can be read as a story about a mnemonic warrior, interested in promoting his version of the past and shaping collective memory in a certain way. Politically motivated stories told by mnemonic warriors and their use of traumatic past may be examples of potentially problematic postcolonial narratives. Svetlana Aleksievich's War's Unwomanly Face, a story about World War II based on the lived experiences of former Soviet women fighters, and Jasmina Husanović's account about "politics of witnessing and hope" and her own political activism are examples of the ways in which engaging trauma narratives can help to transcend the boundaries imposed by specific political groups. My choice of the "Other" Europe was not accidental; there is no shortage of historical trauma and memory politics in this region. Furthermore, the questions raised by the movement to decolonize trauma theory, especially about the ways to avoid new sources of pain and subjugation when trying to address the traumas of the past, are of critical importance in this context.

My analysis of these three articles addressing the commodification of trauma suggest several additional conclusions. First, there are multiple variables affecting the construction and, perhaps most importantly, the reception of postcolonial trauma stories. They include power structures, broader political contexts and existing local and international norms. Not all postcolonial stories get heard, especially internationally. It is important to identify those power structures that make some stories heard (and conversely keep other stories hidden) and ask questions that sometimes may be uncomfortable about the reasons why some stories get heard and some do not.

Second, the evidence from Eastern Europe suggests that "decolonization" of trauma theory does indeed imply a disaggregation of monumental traumas. This approach is especially visible in Kõresaar's and Aleksievich's works. Kõresaar shows how war "touched" individual lives and became part of complicated and even problematic life stories. Aleksievich deconstructs the myth about victory in the "Great Patriotic War" by zooming in on details experienced by women during war. Paying attention to everyday politics, everyday history is a way to "disaggregate" traumas and thus show respect for their complexity. Disaggregation of monumental traumas and challenges to 
political myths that are likely to accompany such moves do not necessarily have to be classified or described as "non-Western" or "anti-Western". Perhaps moves such as the one successfully completed by Aleksievich can be best characterized as attempts to search for commonalities between different traumatic experiences on the micro (individual, family, or community) level.

Third, Jasmina Husanović's story raises intriguing questions about the knowledge of widespread trauma (including everyday trauma resulting from discrimination and injustice that those who argue for decolonization of trauma theory emphasize), writing about the trauma and getting engaged in political actions to address the trauma. Husanović is actively engaged in creating safe transcultural spaces for empowering activities for people who have experienced trauma to take place. In fact, it is possible to argue that activism is what (at least partially) makes Husanović's story so powerful and appealing; she is not afraid to become part of the story that she is writing about; she is not afraid to show her empathy for the bodies whom she is describing. As an openly feminist writer and activist, she goes beyond recording and acknowledging the suffering of "others". Their pain becomes her pain. For such writers and scholars, an "attunement to previously unheard suffering" ([1], p. 37) comes with a personal commitment to political and social change.

Acknowledgments: I would like to thank the faculty, administration and staff of Georgia Gwinnett College for their generous support during my academic leave in Fall 2015 when this essay was written. I would also like to thank Michael Lewkowicz, Ian Peddie, Violeta Davoliūtè, Dalia Cidzikaitè, the anonymous reviewers and the academic editor of this issue for their useful comments and suggestions on the previous drafts of this essay.

Conflicts of Interest: The author declares no conflict of interest.

\section{References}

1. Stef Craps. Postcolonial Witnessing: Trauma Out of Bounds. Basingstoke: Palgrave Macmillan, 2012.

2. Jocelyn Martin. “Manilaner's Holocaust Meets Manileňos' Colonization: Cross-Traumatic Affiliations and Post-Colonial Considerations in Trauma Studies." Humanities 4 (forthcoming).

3. Beatriz Pérez Zapata. “Decolonizing Trauma: A Study of Multidirectional Memory in Zadie Smith's 'The Embassy of Cambodia'." Humanities 4 (2015): 523-34. [CrossRef]

4. Justine Seran. "Australia Aboriginal Memoirs and Memory: A Stolen Generation Trauma Narrative." Humanities 4 (2015): 661-75. [CrossRef]

5. Debarati Sanyal. Memory and Complicity: Migrations of Holocaust Remembrance. New York: Fordham University Press, 2015.

6. Alexander Etkind. Warped Mourning: Stories of the Undead in the Land of the Unburied. Stanford: Stanford University Press, 2013.

7. Cathy Caruth. Unclaimed Experience: Trauma, Narrative, and History. Baltimore: Johns Hopkins University Press, 1996.

8. Svetlana Alexievitch. U Voiny—Ne Zhenskoie Litso (The Unwomanly Face of War). Moscow: Palmira, 2004.

9. Jasmina Husanović. “The Politics of Gender, Witnessing, Postcoloniality and Trauma: Bosnian Feminist Trajectories." Feminist Theory 10 (2009): 99-119. [CrossRef]

10. Jasmina Husanović. "Economies of Affect and Traumatic Knowledge: Lessons on Violence, Witnessing and Resistance in Bosnia and Hercegovina." Etniškumo Studijos/Ethnicity Studies 2 (in print).

11. Ene Kõresaar. "Introduction. Remembrance Cultures of World War II and the Politics of Recognition in Post-Soviet Estonia: Biographical Perspectives." In Soldiers of Memory: World War II and Its Aftermath in Estonian Post-Soviet Life Stories. Edited by Ene Kõresaar. Amsterdam: Rodopi, 2011, pp. 1-34.

12. Ene Kõresaar. "Boris Takk-An Ambiguity of War in a Post-Soviet Life Story." In Soldiers of Memory: World War II and Its Aftermath in Estonian Post-Soviet Life Stories. Edited by Ene Kõresaar. Amsterdam: Rodopi, 2011, pp. 343-63.

13. Alexander Etkind. Internal Colonization: Russia's Imperial Experience. Cambridge: Polity Press, 2011.

14. Ewa Thompson. Imperial Knowledge: Russian Literature and Colonialism. Westport and London: Greenwood Press, 2000.

15. Dariusz Skórczewski. Teoria-Literatura-Dyskurs. Pejzaż Postkolonialny (Theory-Literature-Discourse: The Postcolonial Landscape). Lublin: Wydawnictwo KUL, 2013. 
16. Gayatri Chakravarty Spivak. "Are you Postcolonial? To the Teachers of Slavic and Eastern European Literatures." PMLA 121 (2006): 828-29.

17. Mark R. Beisinger, Crawford Young, eds. Beyond State Crisis? Post-Colonial Africa and Post-Soviet Eurasia in Comparative Perspective. Washington: Woodrow Wilson Center Press, 2002.

18. Stefan Troebst. "Halecki Revisited: Europe's Conflicting Cultures of Remembrance." In A European Memory? Contested Histories and Politics of Remembrance. Edited by Małgorzata Pakier, and Bo Stråth. New York: Berhahn Books, pp. 56-63.

19. Eva-Clarita Pettai, ed. Memory and Pluralism in the Baltic States-Rethinking the Relationship. London: Routledge, 2011.

20. Evgeny Finkel. "In Search of Lost Genocide: Historical Policy and International Politics in Post-1989 Eastern Europe." Global Society 24 (2010): 51-70. [CrossRef]

21. Dovile Budryte. "We Call It Genocide': Soviet Deportations and Repression in the Memory of Lithuanians." In The Genocidal Temptation: Auschwitz, Hiroshima, Rwanda, and Beyond. Edited by Robert S. Frey. Lanham: University of America Press, 2004, pp. 223-51.

22. Johan Dietsch. Making Sense of Suffering: Holocaust and Holodomor in Ukrainian Culture. Lund: Lund University Press, 2006.

23. Rebekah Moore. "'A Crime against Humanity Arguably Without Parallel in European History': Genocide and the 'Politics' of Victimhood in Western Narratives of the Ukrainian Holodomor." Australian Journal of Politics and History 58 (2012): 367-79. [CrossRef]

24. Georgii Kas'ianov. "The Holodomor and the Building of a Nation." Russian Social Science Review 52 (2011): 71-93. [CrossRef]

25. John-Paul Himka. "The Lontsky Street Prison Memorial Museum: An Example of Post-Communist Negationism." In Perspectives on the Entangled History of Communism and Nazism: A Comnaz Analysis. Edited by Klas-Gőran Karlsson, Johan Stenfeldt, and Ulf Zander. Lanham: Lexington Books, pp. 137-66.

26. Volodymir Kulyk. "Tautiškumas prieš sovietiškumą: Istorinè atmintis nepriklausomoje Ukrainoje (Nationalism against Sovietism: Historical Memory in Independent Ukraine)." In Atminties Kultūru Dialogai Ukrainos, Lietuvos, Baltarusijos (ULB) Erdvejje (Dialogues of Memory Cultures in the Ukrainian, Lithuanian and Belarussian Space). Edited by Alvydas Nikžentaitis and Michał Kopczyński. Vilnius: Lietuvos Istorijos Instituto Leidykla, 2015, pp. 181-95.

27. Zehavit Gross, and Doyle Stevick, eds. As Witnesses Fall Silent: 21st Century Holocaust Education in Curriculum, Policies and Practice. Cham: Springer International Publishing, 2015.

28. Violeta Davoliūtè. The Making and Breaking of Soviet Lithuania. London: Routledge, 2013.

29. Saulius Sužiedèlis, and Šarūnas Liekis. "Conflicting Memories: The Reception of the Holocaust in Lithuania." In Bringing the Dark Past to Life: The Reception of the Holocaust in Post-Communist Europe. Edited by Joanna Michlic and John-Paul Himke. Lincoln: University of Nebraska Press, 2013, pp. 319-51.

30. Violeta Kelertas. "Introduction: Baltic Postcolonialism and Its Critics." In Baltic Postcolonialism. Edited by Violeta Kelertas. Amsterdam: Rodopi, 2006, pp. 1-10.

31. Claudia Snochowska-Gonzalez. "Post-Colonial Poland-On an Unavoidable Misuse." East European Politics and Societies and Cultures 26 (2012): 708-23. [CrossRef]

32. David Chioni Moore. "Is the Post- in Postcolonial the Post- in Post-Soviet? Toward a Global Postcolonial Critique." Atlas of Transformation. Available online: http://monumenttotransformation.org/atlas-oftransformation/html/p/postcolonial-post-soviet/is-the-post-in-postcolonial-the-post-in-post-soviet-towarda-global-postcolonial-critique-david-chioni-moore.html (accessed on 14 January 2016).

33. Epp Annus. "The Problem of Soviet Colonialism in the Baltics." The Journal of Baltic Studies 43 (2012): 21-45. [CrossRef]

34. Dovile Budryte. Taming Nationalism? Political Community Building in the Post-Soviet Baltic States. Aldershot: Ashgate, 2005.

35. Jan Kubik, and Michael Bernhard. "A Theory of the Politics of Memory." In Twenty Years after Communism: The Politics of Memory and Commemoration. Edited by Michael Bernhard and Jan Kubik. Oxford: Oxfrod University Press, 2014.

36. Elizabeth Jelin. State Repression and the Labors of Memory. Minneapolis: University of Minnesota Press, 2003.

37. Boris Takk. "My Youth as the Turn of History." In Soldiers of Memory: World War II and Its Aftermath in Estonian Post-Soviet Life Stories. Edited by Ene Kõresaar. Amsterdam: Rodopi, 2011, pp. 187-208. 
38. Tiina Ann Kirss. "When is the War Over? Ylo-Vesse Velvelt's Life Story and Surviving the 'Czech Hell'." In Soldiers of Memory: World War II and Its Aftermath in Estonian Post-Soviet Life Stories. Edited by Ene Kõresaar. Amsterdam: Rodopi, 2011, pp. 365-83.

39. Christine Sylvester. "Experiencing War: An Introduction." In Experiencing War. Edited by Christine Sylvester. London: Routledge, 2011, pp. 1-7.

40. Megan Mackenzie. "Ruling Exceptions: Female Soldiers and Everyday Experiences of Civil Conflict." In Experiencing War. Edited by Christine Sylvester. London: Routledge, 2011, pp. 64-78.

(C) 2016 by the author; licensee MDPI, Basel, Switzerland. This article is an open access article distributed under the terms and conditions of the Creative Commons by Attribution (CC-BY) license (http:/ / creativecommons.org/licenses/by/4.0/). 